63 巻 605 号 $(1997-1)$

\title{
往復圧縮機配管系の振動解析技術の開発*
}

\author{
若 林昭 宏*1, 新井茂*1, 山田栄*2
}

\section{Dynamic Study of Piping Systems for Reciprocating Compressors}

\author{
Akihiro WAKABAYASHI, Shigeru ARAI and Sakae YAMADA
}

\begin{abstract}
This paper describes a direct method for studying vibration of piping systems for reciprocating compressors, based on the requirements given by API-618 Design Approach-3. The reliability of this direct method is examined by some experiments with a test piping system using pressure pulsation and nodal vibration measurements. Overall pressure pulsation amplitude and its frequency components at each measurement point agree well with the results from numerical analysis. Close evaluation of "pipe-support' stiffness" and boundary conditions are necessary to perform dynamic analysis of the piping system in relation to the pressure pulsation generated by the reciprocating compressor ; they affect the accuracy of the final estimation of nodal displacement distribution of the piping system.
\end{abstract}

Key Words: Flow-Induced Vibration, Boundary Condition, Principle of Virtual Work, Pressure Pulsation, API-618 Design Approach-3

1. 緒言

化学プラントなどで良く用いられる往復圧樎機まわ りの配管系では, 吸入や吐出の間欠的な流量変動が原 因となって眽動が生じる。配管系の眽動が大きい場 合には機械振動を生じせたり，また，压樎機に対し ては性能低下や動力損失をもたらすこともある。

従って，このような皎置の設計においては，事前に眽 動解析を行い通切な眽動防止法を検郡しておかなけれ ばならない。

国際技術規格（API-618）は，往復圧樎機の設計段 階における㭛動の制御を規定しており，压縮機と配管 系のアコースティックな相互干涉を考虑した㭛動解析 (Design Approach-2) 及び哌動による配管系の振動応 答解析 (Design Approach-3) を必要としている.

従来，㭛動解析の方法は配管系を等価な電気回路に 置き換えアナログでシミュレートする“アナログ解析 法”が主流であったか，本手法においては被雑な配管系 の場合、テータ作成，配線作業に多大な時間を要する 他，アナログ量を取り扱うため，電気素子の精度管理 に問題があった。

伝连マトリックス法(2)(3)は計算時間が短くて済むと いう反面，化学プラントに代表されるブランチが絡ま

* 原稿受付 1996 年 1 月 19 日.

*1 正員, 日立テクノ(株) (恶 300 土浦市神立東 2-28-4).

*2 正員, 卜キコ技研(株)（画210 川崎市川崎区富士見 1-6-3).
りあった配管系や，多数のシリンダが付いた場合は， 流路の定義が煩雜となり取り扱いが面倒になるという 欠点がある。

以上を改善したのが䣓性マトリックス法(1)(4)である 棈造解析で用いる力と変位の関係を表す㣚性マトリッ クスを流量と压力の関係に置き換え，管路が網目にな った非常に複雑な経路を持つ配管系の压力脈動を容易 に解析できるようにした。

筆者らが開発した解析手法(5)(6)(7)は，剛性マトリッ クス法に基つく眼動解析を基本にしているが，さらに， 㭛動計算結果より，配管に作用する加振力を直接計算 し、配管系の振動応答までを設計段階で一度に解析す ろのを可能としたところに特徵を有する。 また，本 手法は API-618 Design Approach-3 を完全に满足す るものであり，本手法を用いることにより，設計時の 検討時間を大幅に（従来の $1 / 5$ 以下）短樎することが 可能となった.

以下, 解析手法の詳細と信頼性確認試誒結果につい て述べ。

\section{2. 解析手法}

今回開発したテジタル解析は，大きく三つのステッ プにより行われる.

（1）配管系とのアコースティックな相互干涉を考虑し た㭛動解析

(2)㭛動により配管系に作用する動的な加振ベクトル 計算 
(3) 加振ベクトルによる配管系の振動応答解析

Fig.1に哌動解析から配管系の振動応答解析までを 含めた全体の解析フローを示す．配管系を含めた压 樎機の性能や動力を予測するためには，バルブの運動 を考虑した解析が必要になる．バルブの動的挙動が 㭛動解析結果に及ほす影は小さいため，本手法にお いては，バルブの運動解析を本フローとは別に，㭛動 解析結果を基にオフラインで行うことにした。

Fig.1の解析フローを以下に説明する.

1)図中，(1)に示すように，压樎機吸入，吐出流量を 配管内压とシリンダ内圧との連成計算で求める. すなわち, 時刻暦でシリンダ内压と吸人，または吐 出压（眽動含む）を対比し，バルブの開閉時期を求 め，バルブの抵抗係数(8)を加味して流量を求める.

2)図中，(2)に示すように，王樎機の吸入，吐出流量 波形をクランク 1 周期間でフーリエ展開し，周波数 領域における㭛動応答計算を行う。本計算のポイ ントは；

a)㭛動計算は，複雑な配管系にも容易に適用可能 な岡性マトリックス法による。

b)㭛動の減衰抵抗は，周波数ことに共振倍率を基準 に决定する。 オリフィスの抵抗も同様.

3) 図中, (3)に示すように, 各次数の脈動の解析結果 を時間領域で合成し，脈動応答の全振幅を求める.

4 ) シリンダ節点部の眽動值が収束するまで(1) (3)を 綝返した後，図中，(4)に示すように配管の節点の 压力変動分のみを考虑した配管加振力（ベクトル） を求める。本解析では，加振ベクトル： $\overrightarrow{\mathrm{F}} を$

$|\vec{F}|=$ （配管面皘） $\times$ （節点压力脈動） $\cdots$ (1)

として求め, その後, 各方向の分力を計算し，それ を各節点に与えた。加振べクトルは各次数こととに 計算する。

5 ) 図中，(5)に示すように，各次数の加振べクトルに 対応した配管振動応答を下式により計算する。

$$
\left([\mathrm{K}]-\omega^{2}[\mathrm{M}]+\mathrm{j} \cdot 2 \zeta[\mathrm{K}]\right) \cdot\{\mathrm{a}\}=\{\mathrm{F}\} \quad \cdots \quad(2)
$$

本計算のポイントとして。

c)配管の質量マトリックス：[M]は，有限要素法で

一般的な仮想仕事の原理を用いた方法による。

d)配管の用性マトリックス：[K]は，一般的な梁の

静的たわみ理論による。

e)眍管の減衰抵抗は，モード減衰比：とを基準に 决定する。

節点変位（ベクトル）：\{a \}を基に配管の各要素内 応力を求める。

6 ) 図中，(6)に示すように，各次数の応力を合成し， オーバオール值を求める. 応力は, 最大主応力説 に基づき，圭応力で評価する。

以上の解析フローにより，脈動解析から配管振動応答 解析まで一気に実施することができる。

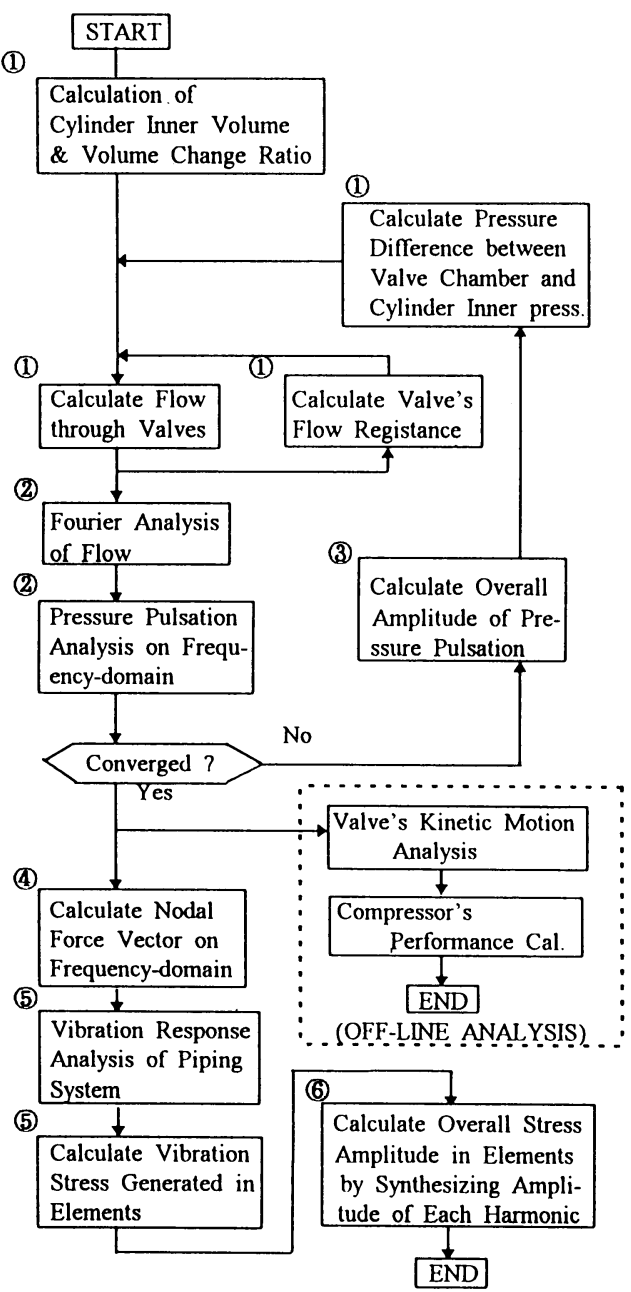

Fig.1 Analysis procedure

\section{3. 実験結果}

3・1 実装国上記の解析手法の信頼性を確認 するため，筆者らは試験配管を用いた実験を行った。

Fig. 2 に試験配管を示す.

実験に用いた压鏥機は一シリンダーの被動機である。 電動機と圧樎機間に無段階減速機を配置することによ り, 王樎機の回転数を $33 \% \sim 100 \%$ の範团で任意に 制御可能とした. Table 1 に圧縮機の仕様を示す.

圧縮機シリンダの機珹的振動の影整を極力絶縁する ために,吐出ポートと配管の接続部にエキスパンショ ンジョイントを設けた，尚，配管とレシーバとの接 続部にも同ジョイントを設置した。 


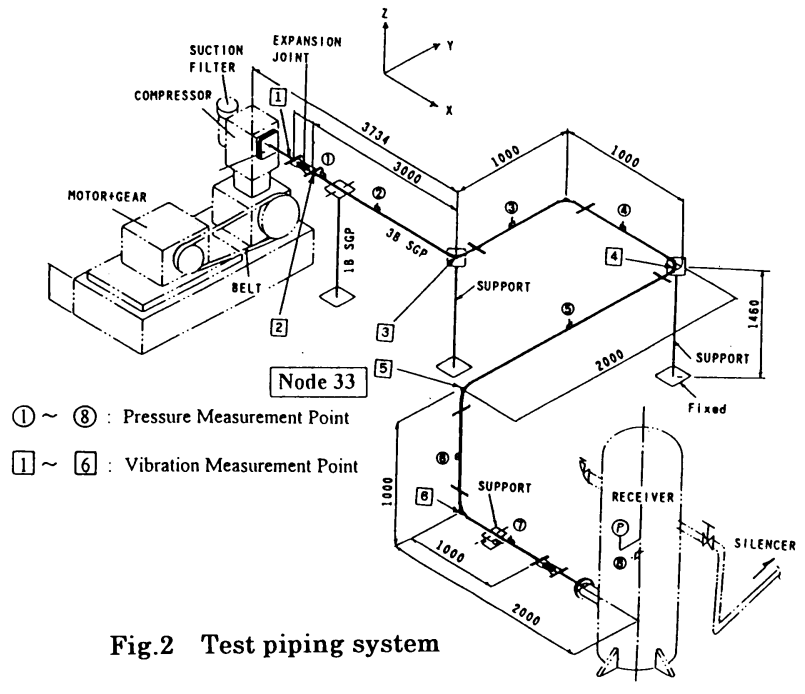

Table 1 Compressor's specification

\begin{tabular}{|l|l|}
\hline Cylinder's diameter & $200 \mathrm{~mm}$ \\
\hline Con.rod ratio & 2.16 \\
\hline Stroke volume & $\begin{array}{c}\text { Head }: 0.00393 \mathrm{~m}^{3} \\
\text { Crank }: 0.00382 \mathrm{~m}^{3}\end{array}$ \\
\hline Clearance ratio & $\begin{array}{c}\text { Head }: 0.067 \\
\text { Crank : } 0.083\end{array}$ \\
\hline Suction pressure & Atmospheric pressure \\
\hline Discharge pressure & $6.9 \times 10^{5} \mathrm{~Pa}$ \\
\hline Rotational speed & $530 \mathrm{rpm}$ \\
\hline Operational condition & Double-acting \\
\hline
\end{tabular}

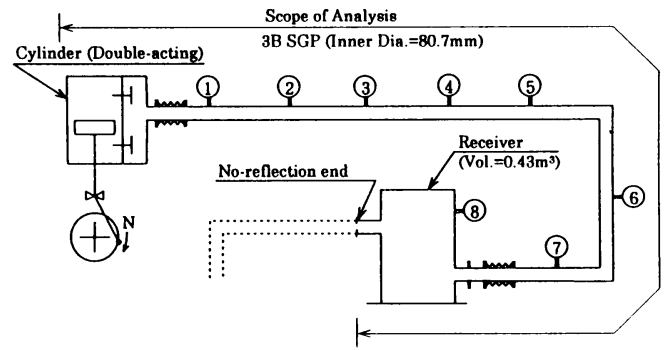

Fig.3 Pulsation analysis model

試験配管の八力所の圧力脈動(Fig.2中，(1)～(8)）と 六力所の配管振動（同図中，凹～因）を計測し，数值 解析結果と比較した。

3・2 解析モテル Fig.3 に压力脈動の解析モデ ルを示す。压䑿機シリンダからレシーバまでを解析 籍囲とした。 また，Fig.4 に振動応答解析モテルを 示す。試験配管は四力所のサポートを有し，この内 三力所については一端固定（アンカー：ベース側）.

一端支持（ヒンジ：配管侧）の等方剛性ハリ（パイプ 材を使用），残り一力所は単純支持（ヒンジ）の境界 条件を模擬した。 以降の振動応答解析はこの境界条 件に基ついている

試験配管の一部であるエキスパンションジョイント の㓮性を解析に反映するため，曲げと引張・圧縮の㣚 性を種々変えて，配管の周波数応答を計算し，実呀に よる固有振動数の測定結果と一致する条件を探した。

Fig. 5 に最適と判断されたエキスパンションジョイ ントの等価剛性評価に基ついて試険配管の周波数応答 を計算した結果を示す。 また，Table 2 に周波数応

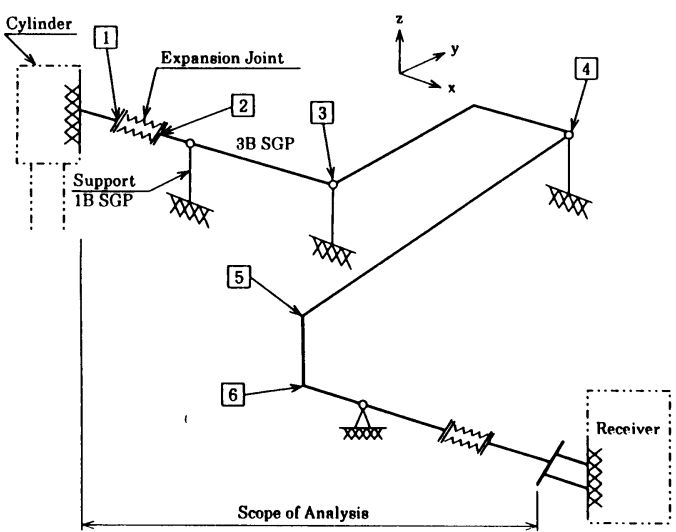

Fig.4 Dynamic analysis model

答計算より求めた固有振動数（Y方向）と測定值との 比較を示す。 1 次と 3 次モ一ドは同時に一致させる ことはできたが， 2 次と 4 次は種々の条件で繰返した が，十分な精度で一致させることはできなかった。 エキスパンションジョイントの取付け時の条件（初期 歪み等）により，断面 2 次モーメントの大きさ，及び 主軸方向が影㹕されているものと考える. Table 3 に等価㓮性評価による最終的なエキスパンションジョ イントの断面積と断面 2 次モーメントを示す. 配管 (3インチ)との比較を参考のために示す. 以降に 示す压樎機運転時の配管振動応答解析は，本条件に基 ついて行った。 


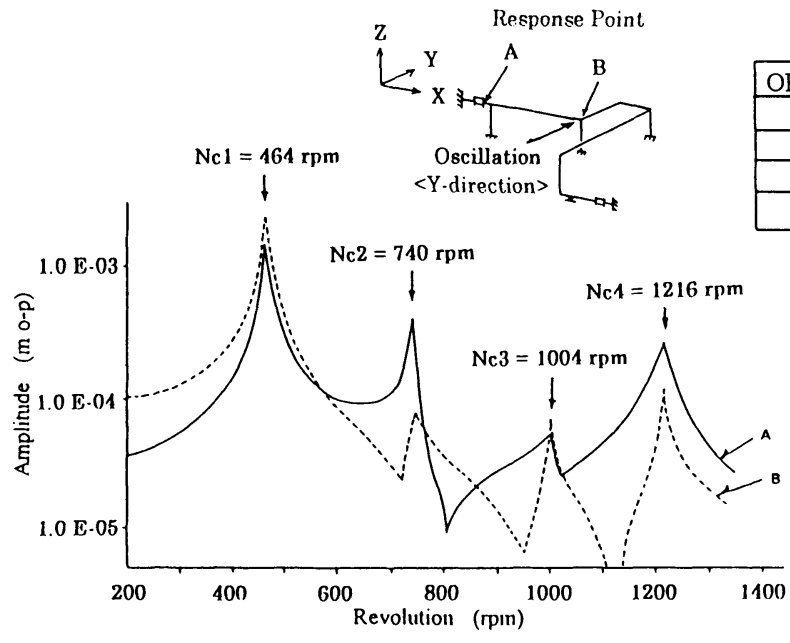

Fig.5 Frequency response of nodal amplitude $<$ Y-direction >

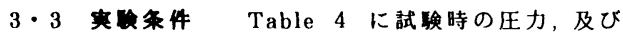
压樎機回転数を示す。試険圧力に関しては，試険時 の配管の沮度上昇を考虑し、またエキスパンションジ ョイントの㣚性に影を及はさない籍囲の圧力として とりうろ最高压力 $\left(2.0 \times 10^{5} \mathrm{~Pa}\right)$ を設定した。压樎機 回転数の影を見るため，定格回転数 $\times 60 ， 80 ， 100 \%$ の条件で実铪を行った。

$3 \cdot 4$ 実結果 Table 5 は各試跧条件におけ る配管系の最大压力眽動振幅の解析值之測定值を比較 したものでありこれらの結果から両者が $10 \%$ 以内の 範囲で良く一致していることがわかる。

同様に，配管の節点 No.33（測定点 5]）における 各方向の振動全振幅 $(\mu \mathrm{mpp})$ を Table 6 に示す. 本結果からは解析值と測定值の一致は CASE-1のみ に見られ，他の試鈋条件においては，両者の比は 0.4 〜 1.15 とばらついている. 各方向の振幅が一致し ない理由は，エキスパンションジョイント，及びサポ 一ト設置時の初期歪みにより，断面 2 次モーメントの 主軸方向が影霜を受け，振動ベクトルの方向にずれが 生じたものと考える。振動べクトルの絶対值：

$\left\{(\mathrm{X})^{2}+(\mathrm{Y})^{2}+(\mathrm{Z})^{2}\right\}^{1 / 2}$ として喏価した場合, CASE-2 除いて解析值と测定值は $5 \%$ 以内の籍囲で良く一致し ていることから，方向のずれの推定は衰付けられる．

CASE-2 の振動ベクトルの解析值と測定值に差を生 じさせる要因として，その他，数值解析上のサポート の境界条件の精度不足が考えられる。即ち，振動応 答解析モデルにおいて，各サポートの境界条件は配管 との接続部をヒンジ（変位拘束，回転フリー）として いるが，実際の試険配管系においては段取り上，この

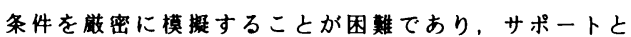
配管との接繶部に回転等探が生じる。サポート他端 においても完全なアンカーを模㩆することが困難であ
Table 2 Natural frequency < Y-direction >

\begin{tabular}{|c|cc|cc|c|}
\hline ORDER & \multicolumn{2}{|c|}{ Measured } & \multicolumn{2}{|c|}{ Analyzed } & Ratio(M/A $)$ \\
\hline 1 & \multicolumn{2}{|c|}{$450 \mathrm{rpm}(7.5 \mathrm{~Hz})$} & \multicolumn{2}{|c|}{$464 \mathrm{rpm}(7.7 \mathrm{~Hz})$} & 0.97 \\
\hline 2 & 570 & $(9.5)$ & 740 & $(12.3)$ & 0.77 \\
\hline 3 & 990 & $(16.5)$ & 1004 & $(16.7)$ & 0.99 \\
\hline 4 & 1800 & $(30.0)$ & 1216 & $(20.3)$ & 1.48 \\
\hline
\end{tabular}

Table 3 Equivalent stiffness evaluation of expansion joint

\begin{tabular}{|l|c|c|}
\hline & $\begin{array}{c}\text { Sectional } \\
\text { Area }\left(\mathrm{mm}^{2}\right)\end{array}$ & $\begin{array}{c}\text { Second Moment } \\
\text { of Area }\left(\mathrm{mm}^{4}\right)\end{array}$ \\
\hline $\begin{array}{c}\text { Expansion } \\
\text { Joint }\end{array}$ & $1.1 \times 10^{3}$ & $0.5 \times 10^{3}$ \\
\hline Pipe & $1.1 \times 10^{3}$ & $1.0 \times 10^{6}$ \\
\hline
\end{tabular}

Table 4 Test conditions

\begin{tabular}{|c|c|c|}
\hline CASE & Pressure & Revolution \\
\hline 1 & $1.0 \times 10^{5} \mathrm{~Pa}$ & S22 $\mathrm{rpm}$ \\
\hline 2 & $0.98 \times 10^{5}$ & 418 \\
\hline 3 & $1.96 \times 10^{5}$ & 322 \\
\hline 4 & $1.0 \times 10^{5}$ & 323 \\
\hline
\end{tabular}

Table 5 Maximum pressure pulsation amplitude

\begin{tabular}{|c|c|c|c|}
\hline CASE & Measured : M & Analyzed : A & Ratio(M/A) \\
\hline 1 & $0.334 \times 10^{5} \mathrm{~Pa}$ & $0.307 \times 10^{5} \mathrm{~Pa}$ & 1.09 \\
\hline 2 & $0.233 \times 10^{5}$ & $0.221 \times 10^{5}$ & 1.05 \\
\hline 3 & $0.285 \times 10^{5}$ & $0.313 \times 10^{5}$ & 0.91 \\
\hline 4 & $0.236 \times 10^{5}$ & $0.248 \times 10^{5}$ & 0.95 \\
\hline
\end{tabular}

Table 6 Nodal displacement at node 33 (OVERALL)

\begin{tabular}{|c|c|c|c|c|}
\hline CASE & Direction & Measured & Analyzed & Ratio(M/A) \\
\hline \multirow{4}{*}{1} & $\mathrm{X}$ & $580 \mu \mathrm{mpp}$ & $627 \mu \mathrm{mpp}$ & 0.93 \\
\cline { 2 - 5 } & $\mathrm{Y}$ & 330 & 293 & 1.13 \\
\cline { 2 - 5 } & $\mathrm{Z}$ & 240 & 197 & 1.22 \\
\hline \multirow{3}{*}{2} & $\mathrm{X}$ & 100 & 157 & 0.64 \\
\cline { 2 - 5 } & $\mathrm{Y}$ & 100 & 248 & 0.40 \\
\cline { 2 - 5 } & $\mathrm{Z}$ & 30 & 55 & 0.55 \\
\hline \multirow{3}{*}{3} & $\mathrm{X}$ & 200 & 302 & 0.66 \\
\cline { 2 - 5 } & $\mathrm{Y}$ & 640 & 586 & 1.09 \\
\cline { 2 - 5 } & $\mathrm{Z}$ & 70 & 108 & 0.65 \\
\hline \multirow{3}{*}{4} & $\mathrm{X}$ & 165 & 245 & 0.67 \\
\cline { 2 - 5 } & $\mathrm{Y}$ & 529 & 459 & 1.15 \\
\cline { 2 - 5 } & $\mathrm{Z}$ & 58 & 87 & 0.67 \\
\hline
\end{tabular}

(MAGNITUDE OF VECTOR)

\begin{tabular}{|c|l|l|c|}
\hline CASE & Measured & Analyzed & Ratio(M/A) \\
\hline 1 & $709 \mu \mathrm{mpp}$ & $720 \mu \mathrm{mpp}$ & 0.98 \\
\hline 2 & 145 & 299 & 0.48 \\
\hline 3 & 674 & 668 & 1.01 \\
\hline 4 & 557 & 528 & 1.05 \\
\hline
\end{tabular}


り、これらが数値解析上のサポートの境界条件の精度 を幾分低下させ，測定值と解析値に差を生じさせたも のと考える。

Fig.6 は CASE-3 の圧力脈動分布と周波数成分の 解析值と測定值を比較したものである。压力眽動分 布の横軸 (NODE.NO.) は，配管系の位置に対応し， 紩軸は压力眽動の全振幅を示す。周波数分析結果の 横軸は，圧樎機回転数を 1 次とした場合の次数（1〜 8 次），綎軸は振幅（片振幅）を示し，四力所の測定 点について解析值と測定值を比較した。Fig.7 測定点(1)，(5)の脈動の時間軸波形の比較を示す. これらより，眽動振幅，周波数成分（主成分）とも解 析值と測定値は，ほほ，10\%以内の籍团で良く一致し ている。 また、時間軸波形についても両者はよく似 ている。

Fig. 8,Fig.9 は CASE-3 の場合の振動振幅分布亡 周波数成分（X，Y方向）に関して解析値と測定值を 比較したものである。これらより，振幅の絶対値に 関しては両者で差が見られるが，配管系全体としての 振動振幅の分布倾向は良く一致している。特に， Y 方向については，振動振幅，周波数成分（主成分）と も解析值と測定值は，ほほ，30\%以内の範囲で良く一 致している.

これらより，本解析手法は脈動応答特性については 実用上十分な精度の解析能力を有すると考える。

また，振動応答特性についても，モテル化時のサポー 卜等の取扱いに留意することにより，解析精度の向上 が図れると考える。
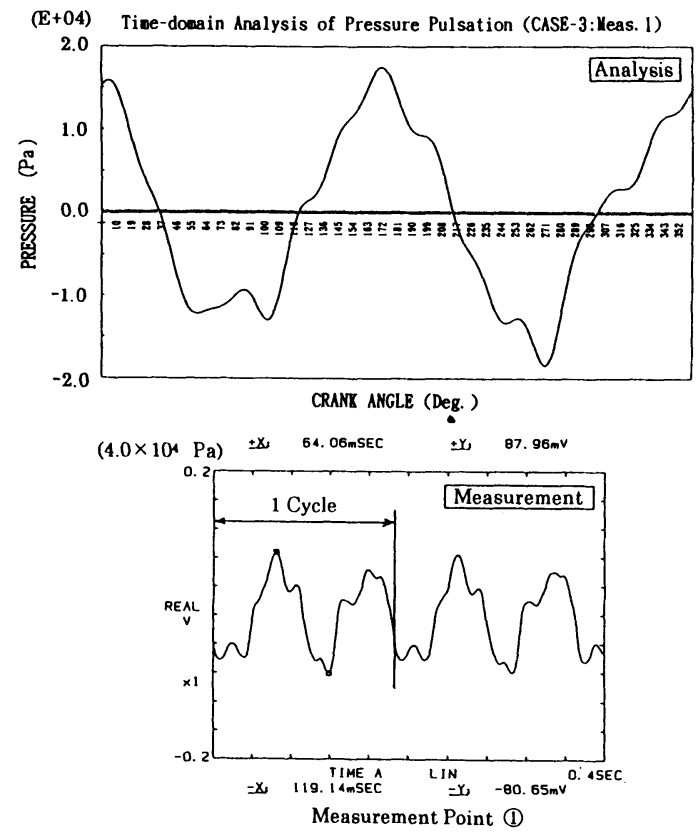
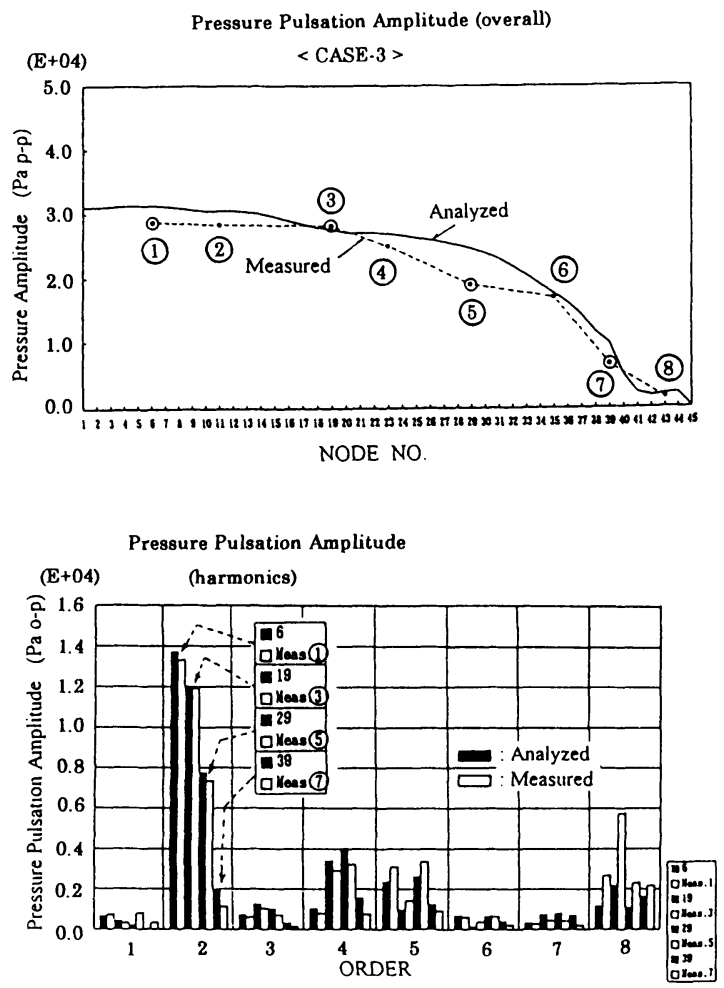

Fig.6 Pressure pulsation amplitude for CASE-3 < overall \& harmonics >
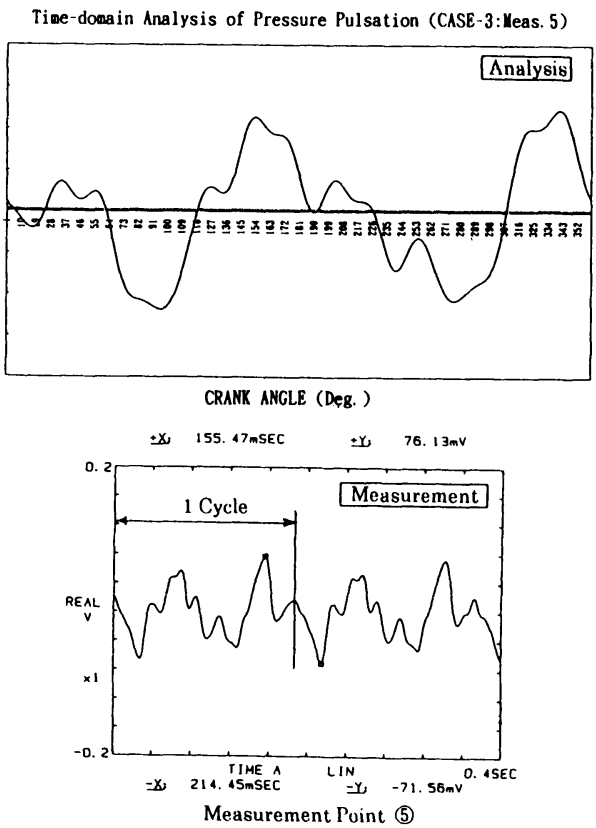

Fig.7 Time-domain analysis of pressure pulsation for CASE-3 

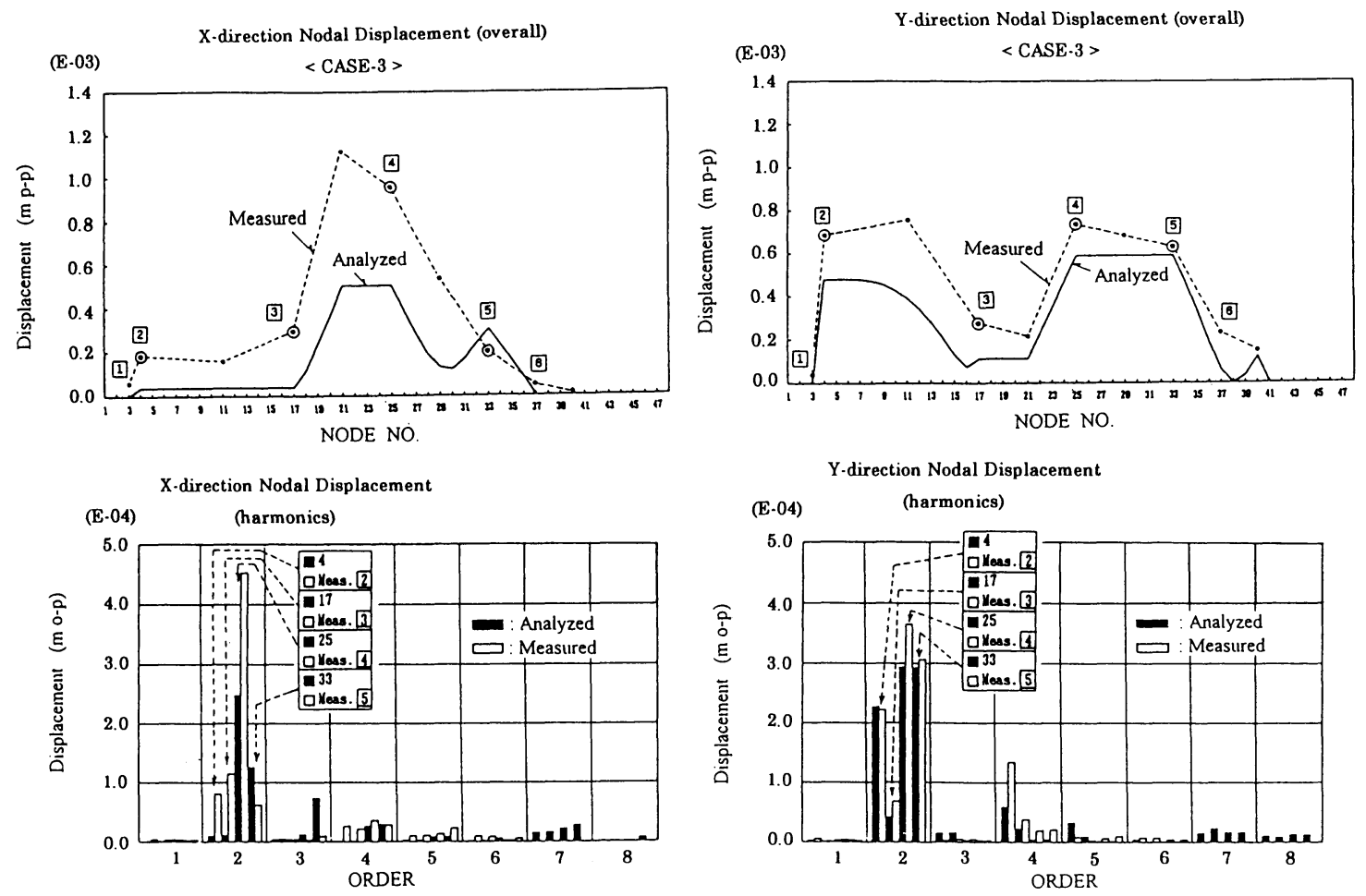

Fig.8 Nodal vibration amplitude for CASE-3 $<$ overall \& harmonics : X-direction >

\section{4. 結言}

本報告では，往復圧樎機配管系の圧力脈動に起因し た振動応答解析技術とその検証武験結果について述へ た。結論は以下の通りである。

（1）压樎機と配管系とのアコースティックな相互干 涉を加味した眽動解析，圧力眽動に起因した配管 加振ベクトル解析，及びこれに基つく配管振動応 答解析を設計段階で一度に実施する手法を開発し た。

（2）試験配管系を用いた検証試鑍結果より，配管系 の压力眽動に関しては，その脈動振幅，及び周波 数成分（主成分）とも解析值と測定値は，ほほ， $10 \%$ 以内算囲で一致しており，実用上十分な精 度の解析能力を有することが確認された。

（３）上記，圧力脈動を加振力とする配管系の振動応 答において，振動の絶対值に関しては，各方向の 振動レベルを合成した振動ベクトルで評価すると 4 ケース中，1つのケースを除き $5 \%$ 以内の籁囲で 解析値と測定值が良く一致した。 モテル化時の サポート等の取扱いに留意することにより，解析 精度の向上が図れることがわかった．

（4）各方向の振動レベルの分布，及び周波数成分に ついては，振幅の絶対値に関して解析値と測定値

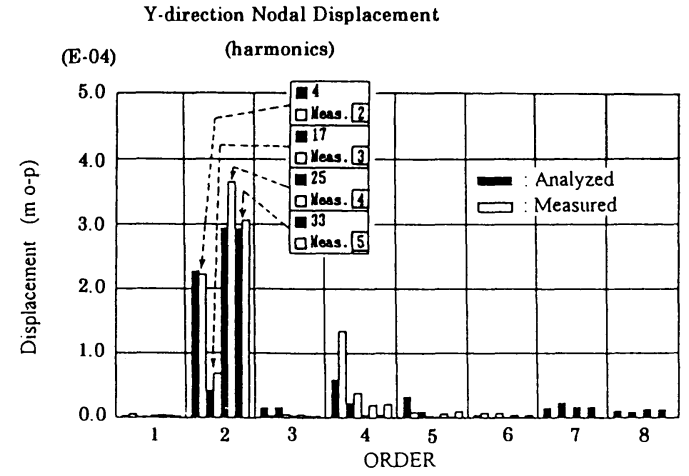

Fig.9 Nodal vibration amplitude for CASE-3 $<$ overall \& harmonics : Y-direction >

に差が見られるが，配管系全体としての振動振幅 の分布傾向は良く一致した。振動レベル分布に ついても俱差 $30 \%$ 程度の解析精度が得られた。

（5）以上より，本報告で提案した手法は，設計段階 で配管系の脈動，振動応答を十分シミュレーショ ン可能であることが確認された．

（6）本手法を適用することにより, 設計時の解析時 間を従来の1/5以下に低隇することができた。

\section{文献}

（1）山田ほか, 流体工学, Vol.10, No.10,(1974), p.647

（2）莱山ほか, 日本機械学会論文集，C，42-364, (1976), p.3825.

（3）松田・葉山，日本機械学会論文集，C，51.463， (1984), p.515

（4）加藤ほか，日本機械学会論文集，C，52.481， (1986), p.2375

( 5 ) Wakabayashi, A., et al., Proc. A.PVC' 93, (1993), p.218

(6) 若林 - 新井 - 山田, $D \& D^{\prime} 95$ 論文集, Vol.B (1995), p.219.

( 7 ) Wakabayashi,A., et al., Proc. PVP' 95, Vol.298, (1995), p. 83

（8）大谷, 日立評論, No.11，(1985), p.14 